\title{
The Determinants of Turkish Outward Foreign Direct Investment
}

\author{
İbrahim Anıl ${ }^{1}$, Ismail Armutlulu ${ }^{1}, \mathrm{Cem} \mathrm{Canel}^{2}$, Rebecca Porterfield ${ }^{2}$ \\ ${ }^{1}$ Faculty of Business Administration and Economics, Department of Business Administration, Marmara University, \\ Istanbul, Turkey \\ ${ }^{2}$ Cameron School of Business, University of North Carolina Wilmington, Wilmington, USA \\ E-mail: porterfieldr@uncw.edu \\ Received July 12, 2011; revised August 20, 2011; accepted September 29, 2011
}

\begin{abstract}
The general theory of Foreign Direct Investment (FDI) has been built on the experience of developed countries' investors. Therefore, there is an extensive amount of literature about firm behaviors in developed countries. Some researchers have started investigating why, how and when developing countries' firms engage in outward FDI. All of these studies have shown that the FDI determinants of firms in newly industrialized economies (NIEs) are different from the FDI determinants of firms in developed economies. This study investigates the entry mode and location choice determinants of Turkish firms' outward direct investments, which are operating in Central Asia, Russia and Balkan Countries, over the period of 1989 to 2005. We find that these investments are associated with high levels of economic and political risks, cultural proximity and lack of ownership advantages. The main purpose of this study is to provide new evidence for these NIE's outward determinants.
\end{abstract}

Keywords: International Business, Manufacturing, Foreign Direct Investment

\section{Introduction}

Many individual Turkish entrepreneurs made investments during the period of 1989-2005 in the Turkic Republics where new market economies emerged following the dissolution of the Soviet Union. These activities were regarded as investment opportunities. Although there have been some studies related specifically to FDI in some Turkic countries [1] there have been few studies about the Turkish FDI's, analyzing why and how those companies chose outward countries for FDI, their competitors, and their performances in those countries.

The direct foreign capital investments of Turkish firms most of which emerged as international firms in this region, reached 4644 billion YTL by 2007. Few international competitors entered these markets, due to perceptions of the high levels of risk and uncertainties involved. Turkish firms, however, have maintained their activities with considerably high performance. This phenomenon cannot be explained through existing international direct investment theories or by current studies on global emerging firms. The involvement of emerging country firms in direct foreign investment is a wholly original phenomenon in terms of theories of direct investment.

Therefore, in this study, data from 107 firms and 169 facilities that directly invested in four Turkic Republics, Bulgaria, Romania and Russia were collected through surveys and in-depth interviews in order to discover the determinants of the investment and location decision making of these firms and the fundamental dynamics of the global emerging firms.

In order to ensure an accurate comparison with developed countries' determinants, the factors affecting the decision making processes of the survey group were obtained using the same determinants used to identify the factors within developed countries. Most of the Turkish firms that went to the Turkic Republics for direct investment decided to find new markets and to use the competitive advantage of being the first to enter into the market. Those firms, which found cheap goods, labor, and quality resources decided to invest in these markets only to find appropriate resources whilst totally ignoring the domestic market. Ironically, some of them wanted to export those products. This study explains the research findings and relates them to existing theories. The next section provides the theoretical framework for this study, 
section three presents the research findings and section four provides conclusions.

\section{Theoretical Framework}

The majority of the information regarding international business administration is based upon analysis of the behavior of firms in developed countries. All the existing theories of direct investment have been shaped and developed in order to explain the behaviors of the firms in developed countries. Bucklet et al., [2] noted that investment by developing countries in developed or developing markets has emerged as a recent focus of research, generally applying existing theories. With the exception of analysis of motivation for FDI in Bulgaria [1], many of the FDI strategies have focused on industry specific motivations [3-5].

The direct capital investments of Turkish firms and of international entrepreneurs display characteristics which differ from the behavior of companies from other developing countries. Hymer [6] used the industrial organization approach to explain the direct foreign capital investments to developed, and developing countries. Several researchers [7-9] attempted a similar analysis utilizing the internalization approach which focuses on the motivation of coordinating interconnected functions for purposes of cost reduction and knowledge sharing. Dunning [10-12] maintained that the internationalization of production is such a complex process that it cannot be explained by a single theory or approach, and as a response developed the more comprehensive eclectical approach created from a synthesis of these two approaches. Other theories developed during the same period include the competitive international industry approach by Vernon $[13,14]$ studies by Kojima [15] to explain Japan's direct investments, and lastly, foreign capital theories based on firm growth theories by Penrose [16] and Screiber [17]. Dunning's eclectical approach, also referred to as the Ownership, Location and Internalization (OLI) approach, maintains a strong position in recent studies [18] According to the OLI approach direct capital investments have the advantages of ownership, benefiting from economies of scale, the skills of technology, patent advantage, brand development and unique management skills allowing for duplication in other geographic locations. The advantages of location are the natural resources of the country, the size of the domestic market, the low input costs such as energy and labor, and taxes and subventions. In the internalization set, the objective is usually to make use of the existing deficient competitor conditions in these countries. In this framework, two of the three basic motives in Dunning's approach were taken as the basis of the analysis of deter- minants of direct investments. Thus, those investing in order to seek market or to seek cheap resources (Efficiency Seeking) have been grouped separately and the differences between them have been explained $[10,19]$.

Global borning firms are the new phenomena in international business literature. Having been established without passing through the Uppsala model which resembles Penrose's company growth theories [20] and through the phases conceptualized in innovation models [21] these companies [22] have been internationalized by reaching the level at which they can sell at least one quarter of their goods abroad within the first three years of their existence. The studies that have been conducted to explain the behavior of the companies in this area [2326] aim to specify the dynamics of global born firms. International born Turkish firms, apart from those, which are global borning firms, are those whose first foundation took place abroad without any ownership advantage. Following the dissolution of the Soviet Union, Turkish companies were established in the newly-independent countries as international firms in order to take advantage of the developed countries' avoidance of these "risky" emerging economies and thus operate in markets free of competition. They were established without concern for the level of technological development so as to benefit from the opportunities presented by the market. Based on the assumption that they would not face competition for a long period, firms even accepted the risks of high costs of implementing the contracts. Some of the Turkish companies operating in developing markets such as Romania, Turkmenistan, Kazakhstan and Bulgaria play important roles in those domestic competitive markets, with billion dollar annual revenues, the developed technology, the distribution channels and the managerial skills they possess. Findings about the international borning Turkish firms are not familiar to scholars studying international investment theories. The emergence into the global economy of Turkish firms has not been the focus of attention amongst theorists and thus, cannot be explained within the framework of generally accepted theories of direct foreign capital investment.

\section{Methodology and Research Findings}

\subsection{Method}

This study focused on identifying the determinants of Turkish FDI's in seven countries based on an equestionnaire survey format developed by Tatoglu and Glaister [27]. The questionnaire was given to 107 firms with wholly owned subsidiaries and 169 facilities in Bulgaria, Romania, Uzbekistan, Kazakhstan, Turkmenistan, Kyrgyzstan and Russia. We personally went to the countries 
and asked the managers who made the investment decisions to fill out the survey forms. With the Foreign Economic Relations Board and the country's commerce consulates, we formed a sample which is calculated from the total census by analyzing the businesses with more than fifty employees. According to our list 20 companies did not wish to participate in the survey, and we had an $84 \%$ response rate. As it can be seen from the total investment amounts shown in Table 1, the majority of the companies consist of small-scale businesses. The average investment amount is 1,704,241 dollars. Table 2 shows the industrial distribution of our sample. The 107 companies in our sample had operations in 129 different sectors. Some of the companies had more than one factory in the same sector, which provided us with 169 companies in our data set.

In this study we used the survey form developed by Tatoglu and Glaister [28]. Tatoglu and Glaister [29] provide the details for the development, accuracy and confidence results of the survey form. The survey form enabled us to compare the results by developed and developing countries. In our study we used a survey form consisting of 16 sections besides the beginning section where company information is presented. Table 3 provides a summary of each of the sixteen sections.

\subsection{Results and Findings}

Table 4 addresses the motivations for country choice by asking "How important were the following factors in your decision to choose the country as a location for investment?" For this study a new question; "to have the advantage of being the first to enter the market" was added to the questionnaire form. The survey and results follow:

Choosing the magnitude of the average as the criterion, the most important factor in determining the choices of country is the "Advantage of being the first to enter the market" with an average score of 4.743 . Other important determinant factors are, "Purchasing power of customers" (3.718) in second position "Level of competition in Industry" third (3.717), "Growth rate of the country" (3.715) fourth, "Size of the Market" fifth (3.463.), "Possibility of obtaining low cost inputs" sixth (3.438), "Easy access to markets of neighboring countries" seventh (3.374), and "Return of the Profit to the country of origin" (3.313), in the eighth position. Market motivation is consistent with the Bitzenis [30] (2007) findings.

According to the analyses conducted with the seconddary data (population, national income level, population size of the Turkish minority, and national income per capita of the country) it can be seen in Table 5 that there is no correlation between the level of investment provided by the Turkish firms and the population, national income level, population size of the Turkish minority, and national income per capita of the country. Similar to the foreign investments by China, Turkish firms invest more in countries where there are Turkish or Turkic minorities in the framework of cultural similarity. [31] The study by Buckley et al., [31] provides the data and analysis related to China.

The Kaiser-Meyer-Olkin measure of sampling adequacy tests whether the partial correlations among variables are small. Bartlett's test of sphericity tests whether the correlation matrix is an identity matrix, which would indicate that the factor model is inappropriate. The next item from the output is the Kaiser-Meyer-Olkin (KMO) and Bartlett's test. The KMO measures the sampling adequacy which should be greater than 0.5 for a satisfactory factor analysis to proceed. Looking at Table 5, the $\mathrm{KMO}$ measure is 0.605 . From the same table, we can see that the Bartlett's test of sphericity is significant. That is, its associated probability is less than 0.05 . In fact, it is actually 0.000 . This means that the correlation matrix is not an identity matrix.

\subsubsection{Distribution of the Determinants in the Seven Countries}

Our analysis showed that 64 of the 107 firms were

Table 1. Countries and companies used in the study.

\begin{tabular}{|c|c|c|c|c|c|c|}
\hline Countries & $\begin{array}{l}\text { Number of } \\
\text { Companies }\end{array}$ & $\begin{array}{c}\text { Small size and } \\
\text { Construction Companies }\end{array}$ & $\begin{array}{c}\text { Number of Target } \\
\text { Companies }\end{array}$ & $\begin{array}{c}\text { Number of responding } \\
\text { Companies }\end{array}$ & $\begin{array}{c}\text { Number of non-responding } \\
\text { Companies }\end{array}$ & $\begin{array}{l}\text { Total Exported } \\
\text { Capital }\left(^{*}\right)\end{array}$ \\
\hline Türkmenistan & 25 & 16 & 9 & 6 & 3 & 57551.386 \\
\hline Russia & 128 & 105 & 23 & 22 & 1 & 188990.715 \\
\hline Romania & 166 & 136 & 30 & 27 & 3 & 151281.240 \\
\hline Uzbekistan & 79 & 60 & 19 & 17 & 2 & 37765.125 \\
\hline Kyrgyzstan & 17 & 6 & 11 & 10 & 1 & 24148.093 \\
\hline Kazakhistan & 100 & 85 & 15 & 11 & 4 & 444157.768 \\
\hline Bulgaria & 56 & 36 & 20 & 14 & 6 & 69227.331 \\
\hline Total & 571 & 444 & 127 & 107 & 20 & 973121658 \\
\hline
\end{tabular}

Resource: $\left(^{*}\right)$ http.www.hazine.gov.tr (Undersecretariat of Treasury statistics (2005). 
Table 2. Distribution of the industry sectors used in the study.

\begin{tabular}{ccccccccccccccc}
\hline Industry & $\mathrm{A}$ & $\mathrm{B}$ & $\mathrm{C}$ & $\mathrm{D}$ & $\mathrm{E}$ & $\mathrm{F}$ & $\mathrm{G}$ & $\mathrm{H}$ & $\mathrm{I}$ & $\mathrm{K}$ & $\mathrm{L}$ & $\mathrm{M}$ & $\mathrm{N}$ & Total \\
\hline Total & 3 & 6 & 25 & 16 & 14 & 3 & 22 & 1 & 9 & 7 & 6 & 2 & 15 & 129 \\
\hline
\end{tabular}

A: Auto, transport; B: Electronics and electrical machinery; C: Food/Drink Manufacturing; D: Textile, apparel and leather; E: Computer and software; F: Metal, iron and steel; G: Other manufacturing; H-Export-import trading; I: Tourism, K: Financial services; L: Architecture, construction services; M: Transport; N: Other services.

our analysis showed that 64 of the 107 firms were "market seeking" and 43 were "resource seeking". Table 6 shows how many firms in each of the countries included in our study was "resource seeking" and how many were "market seeking". It is interesting to note that all of the firms investing in Turkmenistan were "resource seeking" and 21 out of the 22 firms investing in Russia were "market seeking" and 9 out of the 11 firms investing in Kazakhstan were also "market seeking". The number of "resource seeking" and "market seeking" firms in the other four countries does not seem to be significantly different. Table 6 shows the results of the chi-square test where Turkmenistan and Kyrgyzstan are combined in the first phase. In the second phase Romania and Kazakhstan are combined and the hypothesis of Ho: Row and Columns are independent is tested with 5 degrees of freedom in the first phase and 4 degrees of freedom in the second phase. In both phases, this hypothesis could not be rejected.
Table 3. Summary of the survey form.

\begin{tabular}{|c|c|}
\hline Section & Questions' coverage \\
\hline 1 & Company's major activity and relations with the other sectors \\
\hline 2 & Company's entry strategy \\
\hline 3 & Factors that affect the entry strategy \\
\hline 4 & Motivation factors \\
\hline 5 & Company's perceptions of its strengths \\
\hline 6 & $\begin{array}{l}\text { Performance expectations related to various criteria and their } \\
\text { satisfaction level }\end{array}$ \\
\hline 7 & Overall performance of investments \\
\hline 8 & $\begin{array}{l}\text { The performance of the company's investments compared to } \\
\text { home country operations }\end{array}$ \\
\hline 9 & $\begin{array}{l}\text { Performance compared to the competitors in the country of } \\
\text { investment }\end{array}$ \\
\hline 10 & Managerial control over the investment \\
\hline 11 & Management problems areas and their frequency \\
\hline 12 & Similarity of cultures between the host country and company \\
\hline 13 & Percentage of the products purchased from the main company \\
\hline 14 & $\begin{array}{l}\text { Percentage of the products purchased from the investment } \\
\text { company }\end{array}$ \\
\hline 15 & $\begin{array}{l}\text { The existence of the relationship with the host country before } \\
\text { the investment and the form of existing relationship }\end{array}$ \\
\hline 16 & $\begin{array}{l}\text { The factors and how much they are considered during the in- } \\
\text { vestment period }\end{array}$ \\
\hline
\end{tabular}

Table 4. Host country factors for wholly owned subsidiary (WOS) formation. How important were the following factors in your decision to choose the Country as a location for the WOS or JV? $(1=$ of no importance, $5=$ of major importance).

\begin{tabular}{clc}
\hline Question & & \multicolumn{1}{c}{ Factor } \\
\hline 1 & Market size & 3.463 \\
2 & Growth rate of the country's economy & 3.715 \\
3 & Political stability in the country & 2.654 \\
4 & Economic stability in the country & 2.673 \\
5 & Infrastructure development level in the country & 2.654 \\
6 & Possibility of obtaining qualified local labor & 2.415 \\
7 & Foreign investment policy of the government & 3.000 \\
8 & Possibility of obtaining subventions & 2.075 \\
9 & Cost of international transportation and communication & 2.687 \\
10 & Return of profit to the country of origin & 3.313 \\
11 & Possibility of obtaining qualified inputs & 2.396 \\
12 & Possibility of obtaining low cost inputs & 3.438 \\
13 & Tax advantages & 3.986 \\
14 & Geographical proximity & 2.692 \\
15 & Level of trade unionism & 1.358 \\
16 & Purchasing power of customers & 3.718 \\
17 & Level of competition in industry & 3.717 \\
18 & Easy access to markets in neighboring countries & 3.374 \\
19 & Advantage of being the first to enter the market & 4.743 \\
\hline
\end{tabular}


Table 5. Explanatory factor analysis. (a) Turkish investment amounts and average per capita income, population, the ratio of the Turkish Minority and the relation between magnitude of the national income.

\begin{tabular}{ccc}
\hline Kaiser-Meyer-Olkin Measure of Sampling Adequacy. & 0.605 \\
\hline Bartlett's Test of Sphericity ${ }^{* *}$ & Approx. Chi-Square & 472,612 \\
& Df & 120 \\
Sig. & ${ }_{\mathrm{a}} 0.000$ \\
\hline
\end{tabular}

${ }^{a}$ Based on correlations; Rotated Component Matrix.

\begin{tabular}{cccccc}
\hline & Component & & & & \\
\hline & 1 & 2 & 3 & 4 & 5 \\
Economic Stability & $\mathbf{0 . 8 9 2}$ & 0.046 & 0.129 & -0.029 & 0.155 \\
Political Stability & $\mathbf{0 . 8 8 9}$ & 0.059 & 0.113 & -0.095 & 0.149 \\
Repatriability of Profit & $\mathbf{0 . 4 1 4}$ & 0.156 & -0.055 & 0.280 & -0.239 \\
Access to other markets & 0.196 & $\mathbf{0 . 8 3 9}$ & -0.010 & 0.189 & -0.154 \\
Availability of low cost inputs & -0.092 & $\mathbf{0 . 7 3 4}$ & 0.043 & -0.040 & 0.283 \\
Availability of qualified inputs & 0.144 & $\mathbf{0 . 5 7 8}$ & -0.012 & 0.189 & 0.468 \\
Market size & 0.071 & 0.045 & $\mathbf{0 . 8 8 2}$ & -0.125 & 0.005 \\
Purchasing power of customers & -0.084 & -0.167 & $\mathbf{0 . 7 9 0}$ & 0.021 & -0.072 \\
Growth rate of economy & 0.388 & 0.170 & $\mathbf{0 . 5 9 0}$ & 0.135 & -0.053 \\
Degree of unionization & 0.180 & 0.230 & $\mathbf{0 . 3 2 0}$ & 0.147 & 0.126 \\
Geographical proximity & -0.361 & -0.011 & 0.072 & $\mathbf{0 . 8 1 4}$ & -0.128 \\
Level of Infrastructure & 0.108 & 0.114 & -0.061 & $\mathbf{0 . 7 9 2}$ & 0.018 \\
Tax advantages & 0.241 & 0.344 & 0.164 & $\mathbf{0 . 4 5 7}$ & 0.142 \\
Level of industry competition & 0.157 & 0.309 & -0.087 & 0.219 & $\mathbf{0 . 7 2 9}$ \\
First enter to the market & -0.200 & -0.299 & 0.304 & -0.295 & $\mathbf{0 . 4 9 4}$ \\
\hline
\end{tabular}

Extraction Method: Principal Component Analysis. Rotation Method: Varimax with Kaiser Normalization. a Rotation converged in 8 iterations.

(a)

Population Per capita income National income Turkish Investment Total Investment Turkish minority

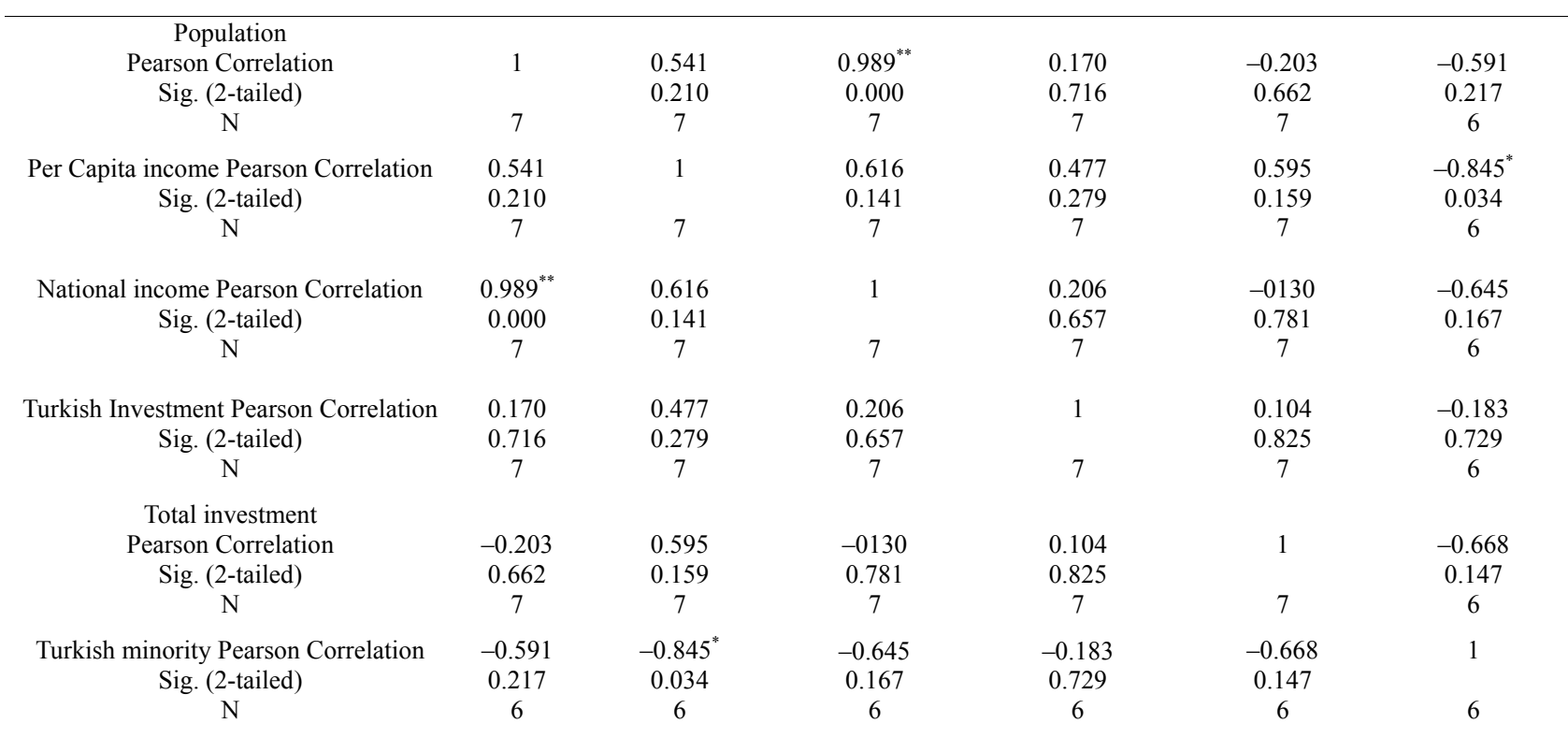

The data used for the analysis of the secondary data was obtained from the related country's statistics (World Investment Report, United Nations Statistics and the Undersecretariat of Treasure Statistics 2005). 
Table 6. Firms distribution according to investing reasons.

\begin{tabular}{ccccccccr}
\hline & \multicolumn{7}{c}{ COUNTRIES } & Total \\
\hline & Turkmenistan & Bulgaria & Kýrgyzstan & Kazakhstan & Romania & Uzbekistan & Russia \\
Resource Seeking & 6 & 7 & 6 & 2 & 11 & 10 & 1 & $\mathbf{4 3}$ \\
Market Seeking & 0 & 7 & 4 & 9 & 16 & 7 & 21 & $\mathbf{6 4}$ \\
Total & $\mathbf{6}$ & $\mathbf{1 4}$ & $\mathbf{1 0}$ & $\mathbf{1 1}$ & $\mathbf{2 7}$ & $\mathbf{1 7}$ & $\mathbf{2 2}$ & $\mathbf{1 0 7}$ \\
\hline
\end{tabular}

\subsubsection{Results of the Factor Analysis Based on the Identified Criteria}

When explanatory factor analysis is applied to the nineteen criteria of investment determinants, the results are distributed under 5 factors as shown in Table 7. The main reason to apply the factor analysis techniques is 1) to reduce the number of variables and 2) to detect structure in the relationships between the variables (to classify them to the most appropriate category).

The criteria "Possibility of obtaining qualified local labor" in question 6, "Foreign investment policy of the government" in question 7 , and "Possibility of obtaining subventions" in question 8 were removed from the differentiating list since they were associated with more than one factor. The first factor consists of criteria that constitute the risk factor: "Economic stability in the country" in question 4, "Political stability in the country" in question 3, "Return of the profit to the country of origin" in question 10 . The second factor consists of criteria that constitute the resource factor: "Easy access to markets of neighboring countries" in question 18, "Possibil- ity of obtaining low cost inputs" in question 12, "Possibility of obtaining qualified inputs" in question 11 . The third factor consists of criteria that constitute the market factor: "Size of the market" in question 1, "Purchasing power of the customer" in question 16, "Growth rate of the country's economy" in question 2, "Level of trade unionism" in question 15. The fourth factor consists of criteria that constitute the logistics factor: "Geographical proximity" in question 14, "Costs of international transportation and communication" in question 9, "Level of development of infrastructure in the country" in question 5. The fifth factor consists of the criteria that constitute the competition factor: "Tax advantages" in question 13, "Level of competition in industry" in question 17, and the "Advantage of being the first to enter the market" in question 19.

\subsubsection{Differences between the Groups in Terms of the Market and Resource Factors}

Among the investment motives of the Turkish firms, it is possible to find two of the three motives that Dunning

Table 7. Rotated component matrix.

\begin{tabular}{|c|c|c|c|c|c|}
\hline & Componen & & & & \\
\hline & 1 & 2 & 3 & 4 & 5 \\
\hline Economic Stability & 0.892 & 0.046 & 0.129 & -0.029 & 0.155 \\
\hline Political Stability & 0.889 & 0.059 & 0.113 & -0.095 & 0.149 \\
\hline Repatriability of Profit & 0.414 & 0.156 & -0.055 & 0.280 & -0.239 \\
\hline Access to other markets & 0.196 & 0.839 & -0.010 & 0.189 & -0.154 \\
\hline Availability of qualified inputs & 0.144 & 0.578 & -0.012 & 0.189 & 0.468 \\
\hline Market size & 0.071 & 0.045 & 0.882 & -0.125 & 0.005 \\
\hline Purchasing power of customers & -0.084 & -0.167 & 0.790 & 0.021 & -0.072 \\
\hline Growth rate of economy & 0.388 & 0.170 & 0.590 & 0.135 & -0.053 \\
\hline Degree of unionization & 0.180 & 0.230 & 0.320 & 0.147 & 0.126 \\
\hline International Transport and communication cost & 0.108 & 0.114 & -0.061 & 0.792 & 0.018 \\
\hline Level of Infrastructure & 0.241 & 0.344 & 0.164 & 0.457 & 0.142 \\
\hline Tax advantages & 0.157 & 0.309 & -0.087 & 0.219 & 0.729 \\
\hline Level of industry competition & -0.200 & -0.299 & 0.304 & -0.295 & 0.494 \\
\hline First enter to the market & 0.036 & 0.032 & -0.018 & -0.045 & 0.261 \\
\hline
\end{tabular}

Extraction Method: Principal Component Analysis. Rotation Method: Varimax with Kaiser Normalization. ${ }^{\mathrm{a}}$ Rotation converged in 8 iterations. 
used in his eclectical approach: investing to seek markets and resources. The two groupings have been used since the companies in this region do not have the opportunity to engage in international growth [32] in order to seek strategic resources and markets.

The firms investing to seek markets were distinguished according to factor analysis, from those investing to seek resources. Their distribution throughout the countries in the study is presented in Table 6. Although the size of the market is a determinant in all studies [33] for a considerable number of the Turkish firms (33\%) it is an unimportant factor in their decisions. The size of the domestic market for international borning Turkish firms is seen as an important determinant with a $90 \%$ reliability level as shown in Table $\mathbf{8}$.

\subsubsection{Analysis of the Advantages of Ownership and Location}

For all the countries in the study, the potential motivetions were measured based on the results from the fourth section of the questionnaire by the fields of benefiting from economies of scale, better resource and capacity use, qualified and privileged access to inputs, presence in new markets, opportunity for rapid entry into markets, investment profitability, harmony with Turkish government policy, cost of contracting and implementation, avoiding the risk of misusing production information, ensuring sufficient quality control, insufficient legislation on patent and license rights, inability to make technology transfers through licensing and patents, and in agencies and licensing. The "gain presence in new markets" by a score of 4.79 out of 5 , "opportunity for rapid entry into markets" by a score of 4.25 , and "investment profitability" by a score of 3.97 are the important factors and the others scoring below an average of 2.5 are the non-significant factors.

International experience, brand and product image, practicing level of technology and managerial information, experience in markets of the chosen country, quality of staff improvement program, staff quality and product differentiation and development skills were measured (based on the results from the fifth section of the questionnaire) as the starting advantages (Ownership) of the firms. It was observed that the founders of the firms, which were born in the country invested in, had international experience by a rate of $2.45 / 5$, practicing level of technology and managerial information by $2.75 / 5$, and the quality of staff improvement program by $2.55 / 5$, whereas they do not possess any of the other starting advantages. The starting advantages for the firms, which originated in Turkey, are above the average of $4.5 / 5$, thus, they fulfill the conditions of traditionally internationalized firms $[6,10,19,34]$.

No statistically significant difference was found between the averages except for product differentiation and development skills, when the starting advantages of those investing for market and those for export were compared in terms of Turkish investments. It could be seen that those investing for the market possess product differentiation and development skills, whereas those investing to export their existing products do not possess a high degree of these skills as presented in Table 9. When the same comparison is made for the direct investments by Turkish owned firms, Table 10 shows that

Table 8. The relationship between the birthplace of the firms and the reasons of expatriation.

\begin{tabular}{|c|c|c|c|c|c|}
\hline & & & QUESTION 2d & & Total \\
\hline & & & Founded in Turkey & Founded Abroad & \\
\hline \multirow[t]{2}{*}{ Resource Seek } & 0.00 & Count & 12 & 31 & 43 \\
\hline & & Expected Count & 16.5 & 26.5 & 43.0 \\
\hline \multirow[t]{2}{*}{ Market Seek } & 1.00 & Count & 29 & 35 & 64 \\
\hline & & Expected Count & 24.5 & 39.5 & 64.0 \\
\hline \multirow[t]{2}{*}{ Total } & & Count & 41 & 66 & 107 \\
\hline & & Expected Count & 41.0 & 66.0 & 107.0 \\
\hline
\end{tabular}

Chi-Square Tests.

\begin{tabular}{cccccc}
\hline & Value & df & Asymp. Sig. (2-sided) & Exact Sig. (2-sided) & Exact Sig. (1-sided) \\
\hline Pearson Chi-Square & 3297 & 1 & .069 & & \\
Continuity Correction & 2601 & 1 & .107 & .067 & .104 \\
Likelihood Ratio & 3360 & 1 & .053 \\
Fisher's Exact Test & & & .071 & \\
Linear-by-Linear Association & 3266 & 1 & & \\
N of Valid Cases & 107 & & & \\
\hline
\end{tabular}

${ }^{\mathrm{a}}$ Computed only for a $2 \times 2$ table; ${ }^{\mathrm{b}} 0$ cells $(.0 \%)$ have expected count less than 5 . The minimum expected count is 16.48 . 
Table 9. The relationship between the reasons of expatriation and the starting advantages (for all firms).

\begin{tabular}{|c|c|c|c|c|c|c|c|c|}
\hline & & $\begin{array}{c}\text { Levene's Test for Equality } \\
\text { of Variances }\end{array}$ & & $\begin{array}{l}\text { st for Equal } \\
\text { of Means }\end{array}$ & & & & \\
\hline & & $\mathrm{F}$ & Sig. & $\mathrm{T}$ & $\mathrm{df}$ & $\begin{array}{c}\text { Sig. } \\
\text { (2-tailed) }\end{array}$ & $\begin{array}{l}\text { Mean Differ- } \\
\text { ence }\end{array}$ & $\begin{array}{l}\text { Std. Error } \\
\text { Difference }\end{array}$ \\
\hline \multirow[t]{2}{*}{$\begin{array}{l}\text { International experience of } \\
\text { company }\end{array}$} & $\begin{array}{l}\text { Equal variances } \\
\text { assumed }\end{array}$ & 0.033 & 0.857 & -1.096 & 95 & 0.276 & -0.399 & 0.3638 \\
\hline & $\begin{array}{c}\text { Equal variances not } \\
\text { assumed }\end{array}$ & & & -1.101 & 77.501 & 0.274 & -0.399 & 0.3621 \\
\hline \multirow{2}{*}{ Trade Mark and Brand Image } & $\begin{array}{l}\text { Equal variances } \\
\text { assumed }\end{array}$ & 0.074 & 0.786 & -0.100 & 95 & 0.921 & -0.039 & 0.3889 \\
\hline & $\begin{array}{l}\text { Equal variances not } \\
\text { assumed }\end{array}$ & & & -0.100 & 76.255 & 0.921 & -0.039 & 0.3891 \\
\hline \multirow[t]{2}{*}{$\begin{array}{l}\text { Technological and } \\
\text { managerial know-how }\end{array}$} & $\begin{array}{l}\text { Equal variances } \\
\text { assumed }\end{array}$ & 4.232 & 0.042 & -0.402 & 94 & 0.688 & -0.137 & 0.3403 \\
\hline & $\begin{array}{l}\text { Equal variances not } \\
\text { assumed }\end{array}$ & & & -0.419 & 86.400 & 0.676 & -0.137 & 0.3266 \\
\hline \multirow[t]{2}{*}{ Experience of foreign market } & $\begin{array}{l}\text { Equal variances } \\
\text { assumed }\end{array}$ & 0.004 & 0.950 & -1.404 & 95 & 0.164 & -0.498 & 0.3550 \\
\hline & $\begin{array}{c}\text { Equal variances not } \\
\text { assumed }\end{array}$ & & & -1.396 & 75.026 & 0.167 & -0.498 & 0.3570 \\
\hline \multirow{2}{*}{ Quality of training programs } & $\begin{array}{l}\text { Equal variances } \\
\text { assumed }\end{array}$ & 0.286 & 0.594 & -0.720 & 94 & 0.473 & -0.234 & 0.3253 \\
\hline & $\begin{array}{c}\text { Equal variances not } \\
\text { assumed }\end{array}$ & & & -0.717 & 75.496 & 0.476 & -0.234 & 0.3268 \\
\hline \multirow[t]{2}{*}{ Quality of personnel } & $\begin{array}{l}\text { Equal variances } \\
\text { assumed }\end{array}$ & 1.431 & 0.235 & -1.304 & 92 & 0.195 & -0.473 & 0.3625 \\
\hline & $\begin{array}{c}\text { Equal variances not } \\
\text { assumed }\end{array}$ & & & -1.285 & 70.798 & 0.203 & -0.473 & 0.3679 \\
\hline \multirow[t]{2}{*}{$\begin{array}{l}\text { Ability to develop } \\
\text { differentiated }\end{array}$} & $\begin{array}{l}\text { Equal variances } \\
\text { assumed }\end{array}$ & 3.327 & 0.071 & -2.898 & 94 & 0.005 & -0.967 & 0.3335 \\
\hline & $\begin{array}{c}\text { Equal variances not } \\
\text { assumed }\end{array}$ & & & -2.991 & 84.231 & 0.004 & -0.967 & 0.3232 \\
\hline
\end{tabular}

there is a significant difference between the averages of those firms that possess a high degree of technology and high managerial information practicing level (with pvalue 0.018), experience in foreign country markets (with p-value 0.015 ), staff quality (probability of type I error 0.048) and product differentiation and development skills (probability of type I error 0.001) went to invest in those countries for the market. The propensity to make use of these advantages is observed in the investments of the Turkish firms which invested to search for markets. The variables shown in Table 9 are based on the fifth section of the questionnaire.

\subsubsection{Analysis of Findings on Risk Taking}

The risk-taking behavior of traditionally internationalized firms is explained by a correlation with the amount of expected inputs [33,35]. Buckley et al., [31] verified that the phenomenon of highly risk-laden direct capital investments ventured by China is also true for the foreign investments by Turkish firms. All of the Turkish firms, except for one operating in Uzbekistan, work at high performance as measured in the seventh section of the questionnaire. It is seen that they have made their investments without considering the risk aspect [36] which verifies the findings of previous studies. No correlation has been found between (United Nations Conference on Trade and Development's (UNCTAD) data on the total investment countries receive and the data of the Undersecreteriat of Treasury of the Turkish Republic. The same is true for risk factor data and COFACE (Country Risk Rating) risk index data. The results are shown in Table 11. Political stability was measured on a $1-5$ likert scale based on the responses to questions three in the third section of the questionnaire.

Based on these results, there is no difference in the importance between those that responded negatively and positively to the criterion of implementation cost of contracts. Those who claimed that it was unimportant ex- 
Table 10. The relationship between the reasons of expatriation and the starting advantages (for the firms located in Turkey).

\begin{tabular}{|c|c|c|c|c|c|c|c|c|}
\hline & & $\begin{array}{c}\text { Levene's Test for Equality } \\
\text { of Variances }\end{array}$ & & $\begin{array}{l}\text { st for Equa } \\
\text { of Means }\end{array}$ & & & & \\
\hline & & $\mathrm{F}$ & Sig. & $\mathrm{T}$ & $\mathrm{df}$ & $\begin{array}{c}\text { Sig. } \\
\text { 2-tailed }\end{array}$ & $\begin{array}{l}\text { Mean Dif- } \\
\text { ference }\end{array}$ & $\begin{array}{l}\text { Std.Error Dif- } \\
\text { ference }\end{array}$ \\
\hline \multirow[t]{2}{*}{$\begin{array}{l}\text { International experience of } \\
\text { company }\end{array}$} & $\begin{array}{l}\text { Equal variances } \\
\text { assumed }\end{array}$ & 0.203 & 0.655 & -1.557 & 39 & 0.127 & -0.749 & 0.4807 \\
\hline & $\begin{array}{c}\text { Equal variances not } \\
\text { assumed }\end{array}$ & & & -1.513 & 19.393 & 0.146 & -0.749 & 0.4947 \\
\hline \multirow[t]{2}{*}{ Trade mark and Brand image } & $\begin{array}{l}\text { Equal variances } \\
\text { assumed }\end{array}$ & 0.907 & 0.347 & -1.010 & 39 & 0.319 & -0.428 & 0.4239 \\
\hline & $\begin{array}{l}\text { Equal variances not } \\
\text { assumed }\end{array}$ & & & -0.943 & 17.946 & 0.358 & -0.428 & 0.4538 \\
\hline \multirow[t]{2}{*}{$\begin{array}{l}\text { Technological and managerial } \\
\text { know-how }\end{array}$} & $\begin{array}{l}\text { Equal variances } \\
\text { assumed }\end{array}$ & 0.799 & 0.377 & -2.482 & 38 & 0.018 & -0.631 & 0.2542 \\
\hline & $\begin{array}{l}\text { Equal variances not } \\
\text { assumed }\end{array}$ & & & -2.189 & 16.276 & 0.043 & -0.631 & 0.2882 \\
\hline \multirow[t]{2}{*}{ Experience of foreign market } & $\begin{array}{l}\text { Equal variances } \\
\text { assumed }\end{array}$ & 1.577 & 0.217 & -2.558 & 39 & 0.015 & -1.374 & 0.5369 \\
\hline & $\begin{array}{l}\text { Equal variances not } \\
\text { assumed }\end{array}$ & & & -2.365 & 17.600 & 0.030 & -1.374 & 0.5809 \\
\hline \multirow[t]{2}{*}{ Quality of training programs } & $\begin{array}{l}\text { Equal variances } \\
\text { assumed }\end{array}$ & 0.766 & 0.387 & -0.763 & 38 & 0.450 & -0.196 & 0.2575 \\
\hline & $\begin{array}{c}\text { Equal variances not } \\
\text { assumed }\end{array}$ & & & -0.731 & 19.066 & 0.474 & -0.196 & 0.2686 \\
\hline \multirow[t]{2}{*}{ Quality of personnel } & $\begin{array}{l}\text { Equal variances } \\
\text { assumed }\end{array}$ & 3.336 & 0.076 & -2.045 & 37 & 0.048 & -0.630 & 0.3078 \\
\hline & $\begin{array}{l}\text { Equal variances not } \\
\text { assumed }\end{array}$ & & & -1.625 & 13.761 & 0.127 & -0.630 & 0.3875 \\
\hline \multirow[t]{2}{*}{$\begin{array}{l}\text { Ability to develop differenti- } \\
\text { ated products }\end{array}$} & $\begin{array}{l}\text { Equal variances } \\
\text { assumed }\end{array}$ & 4.163 & 0.048 & -3.695 & 38 & 0.001 & -1.417 & 0.3834 \\
\hline & $\begin{array}{l}\text { Equal variances not } \\
\text { assumed }\end{array}$ & & & -3.187 & 15.668 & 0.006 & -1.417 & 0.4445 \\
\hline
\end{tabular}

pressed that they accepted the risk in order to achieve the required outcome, whereas those that regarded it as highly important said that this factor ensures a noncompetitive environment and so this aspect was very 
Table 11. Turkish firms and their relationship with the risk dimension of all investments.

\begin{tabular}{|c|c|c|c|c|}
\hline & Total Investment & Turkish Investment & Political Stability & Confidence Index \\
\hline Total Investment Pearson Correlation & 1 & 0.104 & -0.577 & -0.241 \\
\hline Sig. (2-tailed) & & 0.825 & 0.175 & 0.603 \\
\hline $\mathrm{N}$ & 7 & 7 & 7 & 7 \\
\hline Turkish Investment Pearson Correlation & 0.104 & 1 & 0.584 & 0.143 \\
\hline Sig. (2-tailed) & 00.825 & & 0.169 & 0.760 \\
\hline $\mathrm{N}$ & 7 & 7 & 7 & 7 \\
\hline Political Stability Pearson Correlation & -0.577 & 0.584 & 1 & 0.246 \\
\hline Sig. (2-tailed) & 0.175 & 0.169 & & 0.595 \\
\hline $\mathrm{N}$ & 7 & 7 & & 7 \\
\hline Confidant. Index Pearson Correlation & -0.241 & 0.143 & 0.246 & 1 \\
\hline Sig. (2-tailed) & 0.603 & 0.760 & 0.595 & \\
\hline $\mathrm{N}$ & 7 & 7 & 7 & 7 \\
\hline
\end{tabular}

Total Investment Amounts: UNCTAD, Turkish Investment Amounts: Treasure, Political Stability 3.3 Political Stability Standard and Trust Index: COFACE. $\mathrm{H}_{0}$ : "question $2 \mathrm{~d}$ and question 48 are independent from each other". It is rejected at the .05 level of significance.

important in order to sustain the same environment.

None of the Turkish firms surveyed stated that they invested in order to seek strategic resources, and they pointed out that the material conditions in the region were not optimal for investing with such an objective. Furthermore, it is observed that some of these companies established in Turkey aim to benefit from the ownership advantages of OLI when the analyses are conducted on the basis of different investing strategies.

\section{Conclusions}

The purpose of this research was to add to the body of literature in the identification of FDI investments strategies in Turkic countries and to assess the differences from traditional FDI strategy research in developed versus less developed countries.

This research studied the highly risk-laden direct investments of Turkish firms under two sub-groups. International borning firms are established and operate on determinants not explained by existing theories of direct foreign capital investment. The actions of these companies are only partially related to location choice factors.

The choice of markets which are not considered from developed and developing countries due to high cost of contracts is an exceptional situation peculiar to the seven countries which are the focus of this current research. The studies on Foreign Direct Investments examine the investments from companies and analyze them. In this study 42 of the companies are established in Turkey, whereas 65 of them were first established in Turkey showing that $61 \%$ of the companies were first established abroad.

There is a dual structure evident in the direct investments of the Turkish firms in this study. Sixty-four firms invest in order to be the first to enter the market and to operate in a non-competitive environment. Those firms that invested for the market and that possess considerable starting ownership advantages attach importance to cheap and qualified inputs as well as to the size of the market and the purchasing power of the customer. Those companies that invested in order to enter into production in the investment target countries and to export these goods to other countries possess less starting ownership advantages as compared to those investing for the market. Companies setting up production units prefer these countries because of cheap and quality inputs, low business taxes and subvention advantages. Attaching no importance to the domestic market, these firms create a positive externality in the countries in which they invest by supporting the development of industry and exports.

This research indicates that strategic motivations for FDI in Turkic countries are consistent with FDI investment published on developed and developing countries. However in all studies no assessment of the historical origin of the Turkish culture was assessed as to its impact on Turkish investing in Turkics and the correlation with potential historical cultural implications. This information may have reduced the perception of risk due to administrative heritage. A limitation of this study was the nature of the firms surveyed. Further research should yield additional factor information based on subsets of 
the borning firms related to such issues as entrepreneurrial behavior and origins, historic cultural influences as related to risk taking. Due to the rapidly evolving economies of these countries, relevance to development stages could constitute longitudinal studies in better understanding the factor influencers as countries go through different stages of development.

\section{References}

[1] A. Bitzenis, "Determinants of Foreign Direct Investment: Evidence from Multinationals in the Post-Crisis Era of Bulgaria in the Late 1990s," Southeast European and Black Sea Studies, Vol. 7, No. 1, March, 2007, pp. 83111. doi:10.1080/14683850701189352

[2] J. P. Buckley, J. L. Clegg, R. A. Cross, X. Liu, H. Voss and P. Zheng, "The Determinants of Chinese Outward Foreign Direct Investment," Journal of International Business Studies, Vol. 38, No. 4, 2007, pp. 499-518. doi:10.1057/palgrave.jibs.8400277

[3] L. Nachum and S. Zaheer, "The Persistence of Distance? The Impact of Technology on MNE Motivations for Foreign Investment," Strategic Management Journal, Vol. 26, No. 8, 2005, pp. 747-767. doi:10.1002/smj.472

[4] W. Kuemmerle, "The Drivers of Foreign Investment into Research and Development: An Empirical Investigation," Journal of International Business Studies, Vol. 30, No. 1, 1999, pp. 1-24. doi:10.1057/palgrave.jibs. 8490058

[5] D. Williams and D. Deslandes, "Motivation for Service Sector Foreign Direct Investments in Emerging Economics: Insights from the Tourism Industry in Jamaica," The Round Table, Vol. 97, No. 396, 2008, pp. 419-437. doi: $10.1080 / 00358530802057293$

[6] S. H. Hymer, "The International Operations of National Firms," The MIT Press, Cambridge, 1976.

[7] P. J. Buckley and M. Casson, "The Optimal Timing of a Foreign Direct Investment," Economic Journal, Vol. 91, No. 361, 1981, pp. 75-87. doi:10.2307/2231697

[8] A. M. Rugman, "Internalization as a General Theory of Foreign Direct Investment: A Reappraisal of the Literature," Weltwirtschaftliches Archive, Vol. 116, No. 2, 1980, pp. 365-379. doi:10.1007/BF02696864

[9] A. M. Rugman, "Inside the Multinational: The Economics of Internal Markets," Croom Helm, London, 1981.

[10] J. H. Dunning, "Trade, Location of Economic Activity and MNE: A Search for an Eclectic Approach," In: B. Ohlin, P. O. Hesselbaum and P. M. Wijkman, Eds., The International Allocation of Economic Activity, Macmillan, London, 1977, pp. 398-418.

[11] J. H. Dunning, "International Production and the Multinational Enterprise," George Allen and Unwin, London, 1981.

[12] J. H. Dunning, "The Eclectic Paradigm of International Production: A Restatement and Some Possible Extensions," Journal of International Business Studies, Vol. 19, No. 1, 1988, pp. 1-31. doi:10.1057/palgrave.jibs. 8490372
[13] R. Vernon, "International Investment and International Trade in Product Cycle," Quarterly Journal of Economics, Vol. 80, No. 2, 1966, pp. 190-207. doi:10.2307/1880689

[14] R. Vernon, "The Location of Economic Activity," In: J. H. Dunning, Ed., Economic Analysis and Multinational Enterprise, Allen and Unwin, London, 1974, pp. 89-114.

[15] K. Kojima, "Japanese-Style Direct Foreign Investment," Japanese Economic Studies, vol. 4, No. 3, 1986, pp. 50-75.

[16] E. T. Penrose, "Foreign Investment and the Growth of the Firm," Economic Journal, Vol. 66, No. 261, 1956, pp. 220-235. doi: $10.2307 / 2227966$

[17] J. Schreiber, "US Corporate Investment in Taiwan," The Dunellen Compony, New York, 1970.

[18] H. J. Dunning and N. C. Pitelis, “Stephan Hymer's Contribution to International Business Scholarship: An Assessment and Extension," Journal of International Business Studies, Vol. 39, No. 1, 2007, pp. 167-176. doi:10.1057/palgrave.jibs.8400328

[19] J. H. Dunning, "Multinational Enterprises and Global Economy," Addison-Wesley, Wokingham, 1993.

[20] T. J. Steen and W. P. Liesch, "A Note on Penrosean Growth, Resource Bundles and the Uppsala Model of Internationalisation," Management International Review, Vol. 47, No. 2, 2007, pp. 193-206. doi:10.1007/s11575-007-0011-7

[21] G. A. Knight and S. T. Çavuşgil, "Innovation, Organizational Capabilities and the Born-Global Firm," Journal of International Business Studies, Vol. 35, No. 2, 2004, pp. 124-141. doi:10.1057/palgrave.jibs. 8400071

[22] W. J. Bilkey and G. Tesar, "The Export Behavior of Smaller Wisconsin Manufacturing Firms," Journal of International Business Studies, Vol. 8, No. 1, 1977, pp. 93-98. doi:10.1057/palgrave.jibs.8490783

[23] G. A. Knight and S. T. Çavuşgil, "Innovation, Organizational Capabilities and the Born-Global Firm," Journal of International Business Studies, Vol. 35, No. 2, 2004, pp. 124-141. doi:10.1057/palgrave.jibs.8400071

[24] M. W. Rennie, "Global Competitiveness: Born Global," McKinsey Quarterly, Vol. 4, 1993, pp. 45-52.

[25] S. Shane and S. Venkataraman, "The Promise of Entrepreneurship as a Field of Research," Academy of Management Review, Vol. 25, No. 1, 2000, pp. 217-226.

[26] H. Etemad and Y. Lee, "The Knowledge Network of International Entrepreneurship: Theory and Evidence," Small Business Economies, Vol. 20, No. 1, 2003, pp. 523. doi:10.1023/A:1020240303332

[27] E. Tatoglu and K. W. Glaister., "Determinants of Foreign Direct Investment in Turkey," Thunderbird International Business Review, Vol. 40, No. 3, 1998, pp. 279-314. doi:10.1002/tie.4270400306

[28] E. Tatoglu and K. Glaister, "An Analysis of Motives for Western DFI in Turkey," International Business Review, Vol. 7, No. 2, 1998, pp. 203-230. doi:10.1016/S0969-5931(98)00006-7

[29] E. Tatoğlu and W. K. Glaister, "Dimensions of Western 
Foreign Direct Investment in Turkey," Quorum Books, Westport, Connecticut-London, 2000.

[30] A. Bitzenis, "Determinants of Foreign Direct Investment: Evidence from Multinationals in the Post-Crisis Era of Bulgaria in the Late 1990s", Southeast European and Black Sea Studies, Vol. 7, No. 1, 2007, pp. 83-111. doi:10.1080/14683850701189352

[31] J. P. Buckley, J. L. Clegg, R. A. Cross, X. Liu, H. Voss and P. Zheng, "The Determinants of Chinese Outward Foreign Direct Investment," Journal of International Business Studies, Vol. 38, No. 4, 2007, pp. 499-518. doi:10.1057/palgrave.jibs.8400277

[32] S. Makino, C. M. Lau and R. S. Yeh, "Asset-Expolitation versus Asset-Seeking: İmplications for Location Choice of Foreign Direct Investment from Newly Industrialized Economies," Journal of International Business Studies, Vol. 33, No. 3, 2002, pp. 403-421. doi:10.1057/palgrave.jibs.8491024

[33] A. Chakrabarti, "The Determinants of Foreign Direct Investment: Sensitivity Analyses of Cross-Country Regressions," Keyklos, Vol. 54, No. 1, 2001, pp. 89-114. doi:10.1111/1467-6435.00142

[34] H. J. Dunning, "The Eclectic Paradigm as an Envelope for Economic and Business Theories of MNE Activity," International Business Review, Vol. 9, No. 2, 2000, pp. 163-190. doi:10.1016/S0969-5931(99)00035-9

[35] P. J. Buckley and M. Casson, "The Optimal Timing of a Foreign Direct Investment," Economic Journal, Vol. 91, No. 361, 1981, pp. 75-87. doi:10.2307/2231697

[36] M. Demirbağ, R. Güneş and H. Mirza, "Political Risk Management: A Case Study of Turkish Companies in Central Asia and Russia," In: H. Mirza, Ed., Global Competitive Strategies in the New World Economy, Edward Ergar, London, 1998, pp. 283-309. 